\title{
Rola ćwiczeń i przyborów wykorzystywanych w zajęciach ruchowych z osobami starszymi
}

\section{Role of exercise and tools used in physical activities with the elderly}

In recent years there has been an increased interest in forms of activities among older people.

Regular physical exercise performed by seniors slow down the aging process, extend the period of physical and mental fitness. Regular physical activity is one way to counteract adverse processes of involution.

To prevent involution situations, gymnastic, movement, dance, athletics, swimming, or related to other sports exercise can be used.

The study shows the importance of some forms of physical activities for people in old age, and presented examples of exercises and tools used in physical activities with the elderly.

\section{Wstęp}

Obserwując dynamiczny przyrost udziału osób starszych w populacji wszystkich państw członkowskich UE, w tym także i Polski, wydaje się koniecznym zwrócenie uwagi na tę grupę ludzi i przygotowanie społeczne do tego okresu życia. Polityka społeczna winna obejmować różne aspekty, odnosząc się do potrzeb ekonomicznych, zdrowotnych, edukacyjnych, które będą wpływać na proces pomyślnego starzenia. Działania na rzecz szeroko rozumianej aktywizacji osób starszych mogą przyczyniać się do podnoszenia jakości ich życia, a regularne ćwiczenia fizyczne pozwolą utrzymać dłużej sprawność, autonomię i samodzielność w zakresie czynności dnia codziennego. 
Aktywność ruchowa podejmowana regularnie to jeden z czynników istotnie wpływających na zdrowie osób starszych. Niedobór ruchu może prowadzić do przyspieszenia procesów starzenia się oraz niedołęstwa, bowiem bezczynność i bierność w znacznym stopniu obniżają wydolność fizyczną i upośledzają funkcjonowanie wielu układów narządowych (układu krążenia, układu oddechowego, układu ruchu itd.). Dlatego wysiłek fizyczny powinien stanowić wspólny mianownik wszystkich działań prewencyjno-rehabilitacyjnych, niezależnie od stanu zdrowia i sprawności fizycznej osób w starszym wieku. Starzenie się przy nieobecności chorób jest stosunkowo rzadkie, jednak możliwe. Optymalną jego formę określa się jako starzenie się pomyślne. Gębska-Kuczerowska wykazała, że osoby aktywne fizycznie mają lepszą kondycję fizyczną oraz psychiczną, są mniej obciążone chorobami układu krążenia, a także rzadziej korzystają z opieki szpitalnej (Gębska-Kuczerowska, 2002).

W programach aktywizujących osoby starsze, Światowa Organizacja Zdrowia proponuje uwzględniać następujące reguły (Wizner, 2006):

- zajęcia mogą mieć charakter indywidualny i grupowy,

- powinno się stosować różne formy ćwiczeń (stretching), ćwiczenia aerobowe, relaksacyjne,

- ćwiczenia powinny obejmować formy łatwe lub o umiarkowanym stopniu trudności: spacer, taniec, pływanie, jazda na rowerze, gimnastyka,

- składowe ćwiczeń powinny obejmować trening mięśni - ćwiczenia wytrzymałościowe, trening równowagi i „elastyczności”,

- ćwiczenia powinny sprawiać radość i powodować odprężenie,

- powinny być prowadzone regularnie, jeśli to możliwe - codziennie.

Zdaniem Wieczorowskiej-Tobis i wspł. program aktywności fizycznej seniorów powinien zawierać trzy elementy (Wieczorowska-Tobis, Kostka, Borowicz, 2011):

1) ćwiczenia wytrzymałościowe (marsz, bieg, pływanie, jazda na rowerze, narciarstwo biegowe), wykonywane 2-3 razy w tygodniu, co najmniej po 20 min, z intensywnością na poziomie 40-80\% rezerwy częstości skurczów serca (tętno spoczynkowe $+40-80 \%$ różnicy pomiędzy maksymalnym tętnem w czasie próby wysiłkowej i tętnem spoczynkowym;

2) ćwiczenia siłowe, wykonywane dwa razy w tygodniu, po $20 \mathrm{~min}$, zawierające zestaw 8-10 ćwiczeń angażujących najważniejsze grupy mięśniowe, po 10-15 powtórzeń każdego ćwiczenia;

3) ćwiczenia rozciągające, równoważne i koordynacyjne, wykonywane codziennie po 5-10 min.

Ćwiczenia ruchowe osób starszych skierowane są na:

- poprawę wydolności tlenowej (aerobowej),

- wzmocnienie siły mięśniowej,

- poprawę gibkości, równowagi i koordynacji ruchowej.

Jednym z elementów działania aktywizujących starszych ludzi, może być zastosowanie w ćwiczeniach przyborów, które urozmaicają zajęcia, ułatwiają wykonywanie ćwiczeń oraz zwiększają ich obszerność i poczucie bezpieczeństwa. Dzięki nim ćwiczący uczą się również jak wykorzystywać przybory do 
samodzielnego ćwiczenia w domu, jak je zastępować przedmiotami codziennego użytku bez konieczności posiadania oryginalnych.

Przybory są bardzo skutecznym środkiem rozwijania zdolności kondycyjnych i koordynacyjnych (zwłaszcza zwinności i zręczności), a także korygowania wad postawy ciała. Sprawiają, że zajęcia są bardziej atrakcyjne, a stawiane przed ćwiczącymi zadania bardziej konkretne. Mnogość przyborów standardowych (piłki lekarskie, skakanki, laski, hantle itd.), jak i podręcznych (woreczki, gazety, różnego rodzaju opakowania po...) stwarza nieograniczone możliwości urozmaicania zajęć, pobudzania do aktywności i wyzwala inwencję twórczą u ćwiczących.

Z uwagi na wykorzystanie do badań grupy osób starszych, uczestniczących w zorganizowanych modułach zajęć, w pracy ograniczono się do takich przyborów, jak laski gimnastyczne, kije do nordic walking, taśmy thera-band, piłki fit-ball, hantle, trener równowagi, przybory do aqua fitness.

Celem autorów pracy jest ukazanie opinii osób starszych uczestniczących w zorganizowanych zajęciach ruchowych na temat podejmowanej aktywności ruchowej, ze szczególnym uwzględnieniem wykorzystywanych w trakcie zajęć przyborów.

\section{Materiał i metoda}

Materiał badawczy zebrano w 2014 roku. W badaniach przeprowadzonych metodą sondażu diagnostycznego zastosowano technikę ankiety, w której wykorzystano skonstruowany przez badaczy kwestionariusz. Grupę badawczą stanowiło 60 osób, w wieku od 60 lat wzwyż, które regularnie brały udział w zorganizowanych zajęciach ruchowych, podczas których wykorzystywano przybory ćwiczebne. Były to następujące rodzaje zajęć: „Aqua senior”, „Nordic walking”, „Gimnastyka 60+”, „Choreoterapia”, „Pilates”, „Zdrowy Kręgosłup” oraz „Muzykoterapia”.

\section{Wyniki}

Zaprezentowane wyniki badań są tylko wybraną częścią, która została przedstawiona na potrzeby niniejszego opracowania.

W przeprowadzonych badaniach udział wzięło 36 kobiet (60\%) i 24 mężczyzn (40\%). Wiek osób ankietowanych mieścił się w przedziale od 60 do 73 lat. Pod względem wykształcenia 31 osób $(51,7 \%)$ legitymowało się wykształceniem wyższym, 22 osoby $(36,6 \%)$ wykształceniem zawodowym, natomiast pozostałe siedem osób $(11,6 \%)$ wykształceniem średnim.

Analizując odpowiedzi dotyczące aktywności fizycznej w przeszłości, można stwierdzić, że badana grupa charakteryzuje się wysokim stopniem aktywności fizycznej. Dotyczy to zarówno przeszłości, jak i teraźniejszości. Jedynie $20 \%$ spośród badanych nie było w przeszłości osobami aktywnymi i dopiero w starszym wieku próbują nadrobić zaniedbania. 


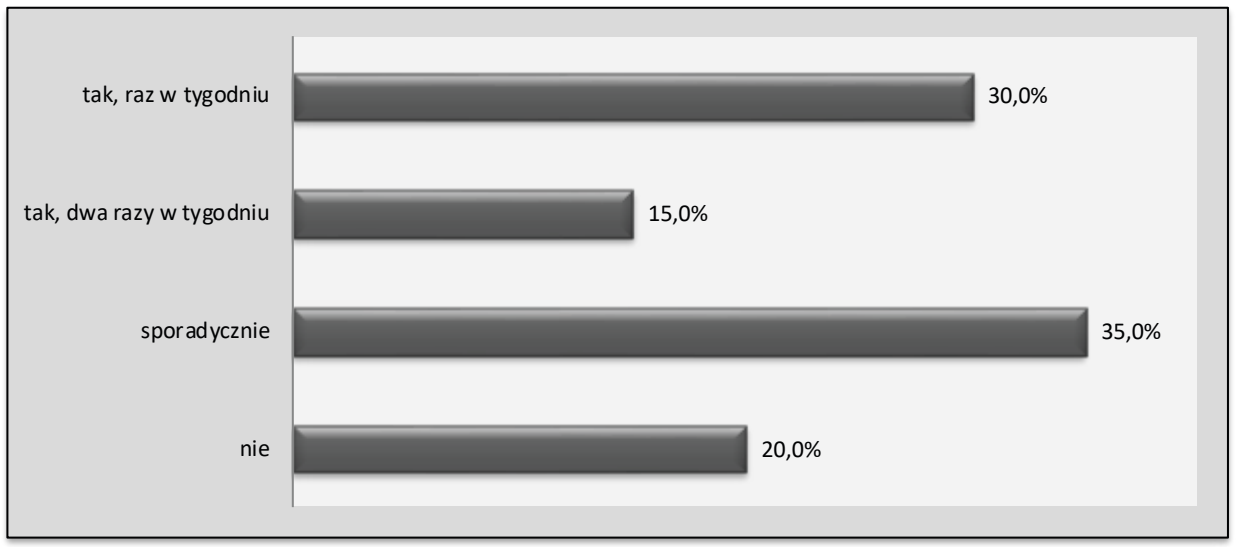

Rycina 1. Podejmowanie aktywności fizycznej przez badanych w przeszłości i obecnie

Źródło: badania własne.

Spośród badanych 59,7\% dodatkowo uprawia inną formę aktywności. Najwięcej, bo $21,6 \%$ zajmuje się nordic walking, a w dalszej kolejności pojawiają się: pływanie, jazda na rowerze, narciarstwo. Jedna osoba deklaruje uprawianie biegania i jedna osoba chodzenie po górach w kategorii „inne”. 40,3\% seniorów ogranicza się do aktualnie wykonywanych ćwiczeń grupowych. Można więc stwierdzić, że grupa ta charakteryzuje się wysokim stopniem aktywności fizycznej.

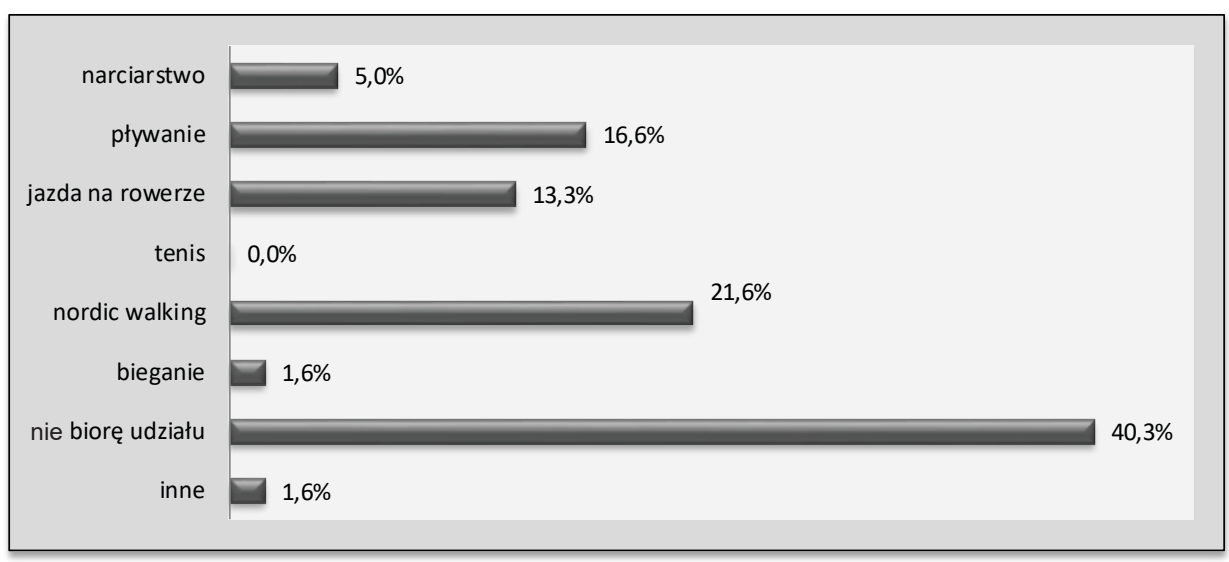

Rycina 2. Udział badanych w zajęciach ruchowych nieobjętych badaniami

Źródło: badania własne.

Rozpatrując status materialny badanych okazuje się, że większość, bo $58,4 \%$ osób, deklaruje swoją sytuację jako przeciętną, 16,7\% jako dobrą i 13,3\% jako bardzo dobrą. W trudnej sytuacji materialnej znajduje się $8,3 \%$ badanych. 
Czynnik materialny wydaje się istotną barierą w dostępności do aktywności fizycznej. Można więc stwierdzić, że badana grupa charakteryzuje się dobrą sytuacją materialną, co jak widać z poprzednich analiz, umożliwia ankietowanym wyższą, ponadprzeciętną, aktywność fizyczną.

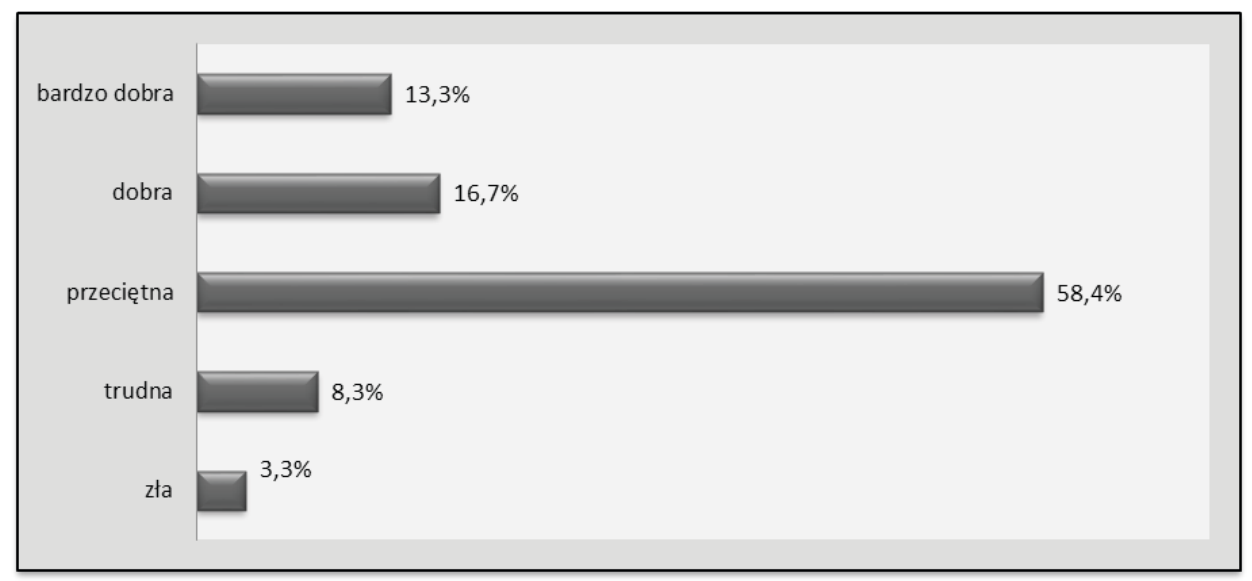

Rycina 3. Sytuacja materialna badanych

Źródło: badania własne.

Odpowiadając na pytanie dotyczące przeszkód w podejmowaniu aktywności fizycznej badani najczęściej podkreślali słabą motywację i nieśmiałość (51,6\% i 46,6\%). W dalszej kolejności pojawiają się wysokie koszty $(31,6 \%)$ i na końcu brak przekonania o pozytywnych skutkach tej aktywności (30\%). Grupa ta posiada więc wiedzę i jest świadoma konieczności podejmowania aktywności fizycznej, raczej nie obawia się wysokich kosztów, a więc jest zdeterminowana, żeby uczestniczyć w zajęciach ruchowych. Jednak nieśmiałość i być może niewiara we własne możliwości oraz problem ze zmobilizowaniem stanowią przeszkody w realizacji zamierzeń.

Odpowiadając na pytanie dotyczące największych plusów z bycia aktywnym, ankietowani najczęściej zaznaczali poprawę samopoczucia $(75,3 \%)$ i potrzebę kontaktu z ludźmi $(58,2 \%)$. Na kolejnych miejscach są poprawa zdrowia $(50,2 \%)$ i redukcja masy ciała $(48,2 \%)$, a na końcu wypełnienie czasu wolnego $(35,5 \%)$. Rozkład odpowiedzi jest interesujący: wydawałoby się, że to problemy zdrowotne powodują większe zainteresowanie aktywnością. Tutaj samopoczucie ogólne wysuwa się na plan pierwszy, a więc chęć utrzymania dobrej kondycji i „formy”, jak również radość wynikająca $z$ bycia w grupie rówieśniczej są dla badanych najważniejsze. Obserwacje geriatrów dowodzą, że samotni seniorzy częściej zapadają na choroby psychiczne, towarzyszy im zmienność nastrojów, lęk, otępienie, niepokój. Tracą motywację do dbania o swoje zdrowie. 


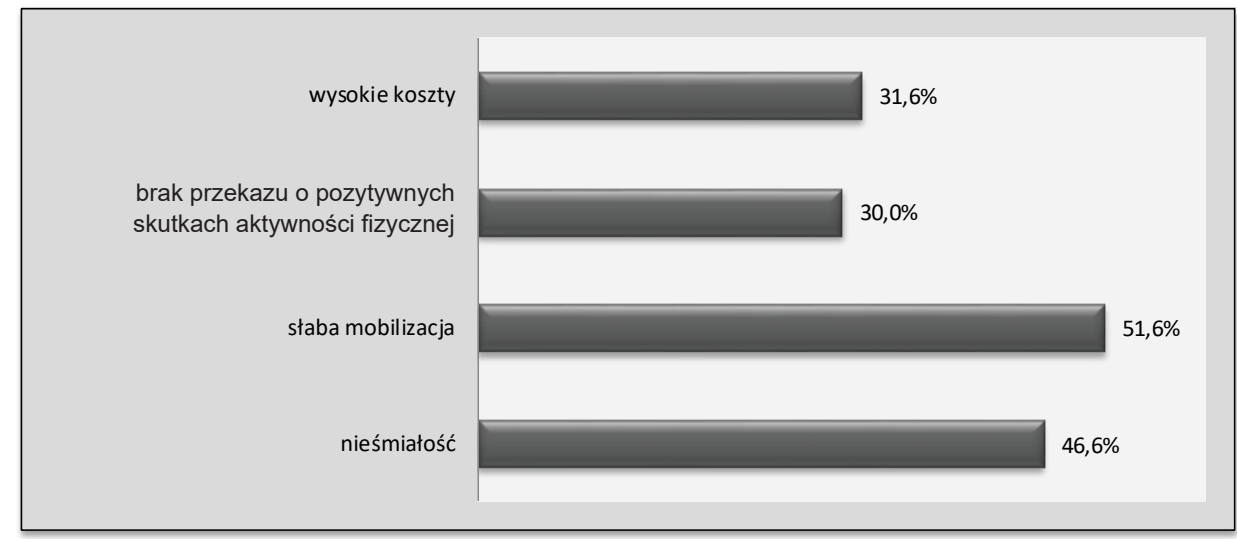

Procenty nie sumują się do 100, gdyż była możliwość wyboru więcej niż jednej odpowiedzi.

Rycina 4. Bariery w podejmowaniu aktywności fizycznej przez badanych

Źródło: badania własne.

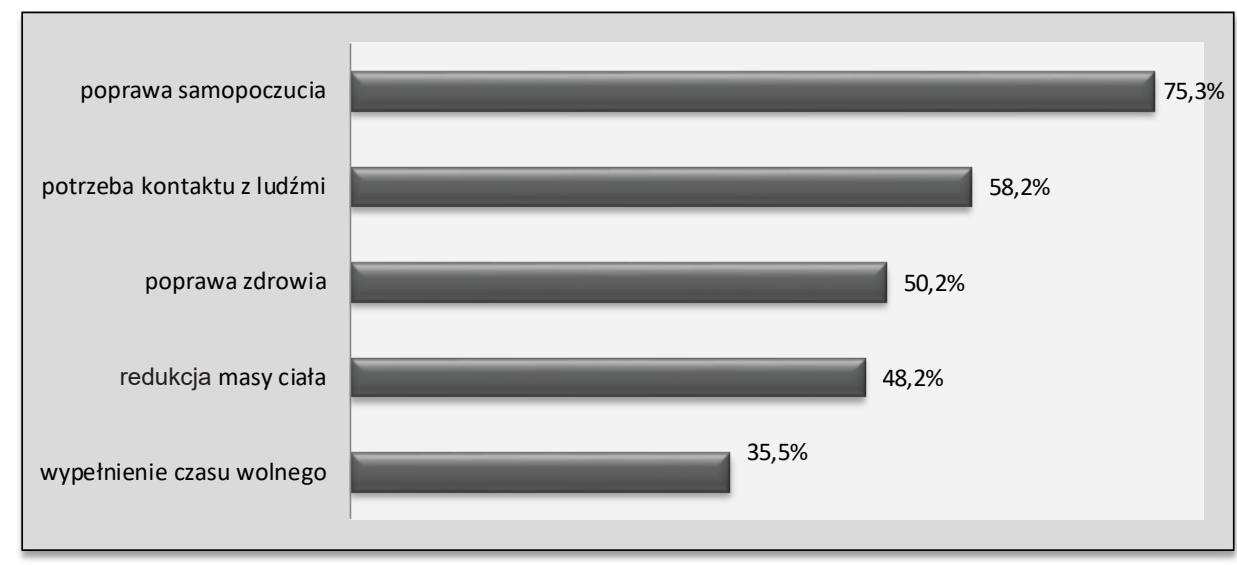

Procenty nie sumują się do 100, gdyż była możliwość wyboru więcej niż jednej odpowiedzi.

Rycina 5. Plusy z podejmowania aktywności fizycznej przez badanych

Źródło: badania własne.

W przypadku użycia przyborów na zajęciach ruchowych wyniki wskazują, że zdecydowana część badanych, bo $85 \%$, preferuje formę ruchu wspomaganą pracą z przyborem. $10 \%$ ankietowanych nie zauważyło różnicy w ćwiczeniu $z$ dodatkowymi pomocami, a zaledwie $5 \%$ badanych nie akceptuje dodatkowych akcesoriów na zajęciach ruchowych. 
zdecydowanie tak - wolę ćwiczyć z przyborem

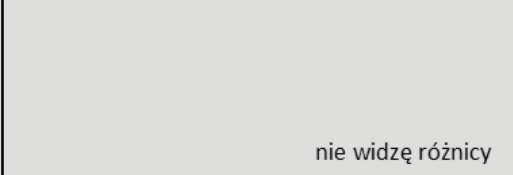

wolę ćwiczyć bez przyborów

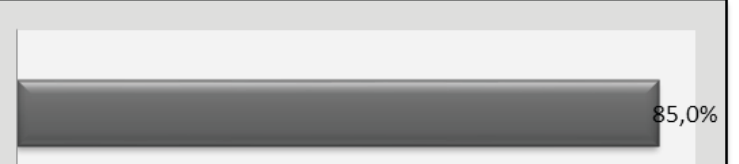

$10,0 \%$

$5,0 \%$

Rycina 6. Zainteresowanie przyborami podczas podejmowania aktywności fizycznej przez badanych

Źródło: badania własne.

Analizując odpowiedzi dotyczące trudności ćwiczeń z przyborami, stwierdzono, że badani muszą bardziej się koncentrować w trakcie ćwiczeń z przyborem - tak odpowiada 53,4\% osób. Dla części - 30\%, ćwiczenia takie wydają się bardziej męczące, a zdaniem 16,3\% nie sprawiają żadnych problemów. Spadająca z wiekiem szybkość reakcji na bodźce zewnętrzne sprawia, że zastosowanie przyboru wymaga większej uwagi i koncentracji. Przybór stanowi dodatkowe obciążenie. Wykonując ćwiczenia z przyborem angażujemy do pracy większą ilość mięśni. Taka praca wypływa pozytywnie na hamowanie rozwoju sarkopenii i przyrost siły mięśniowej, która z wiekiem drastycznie spada.

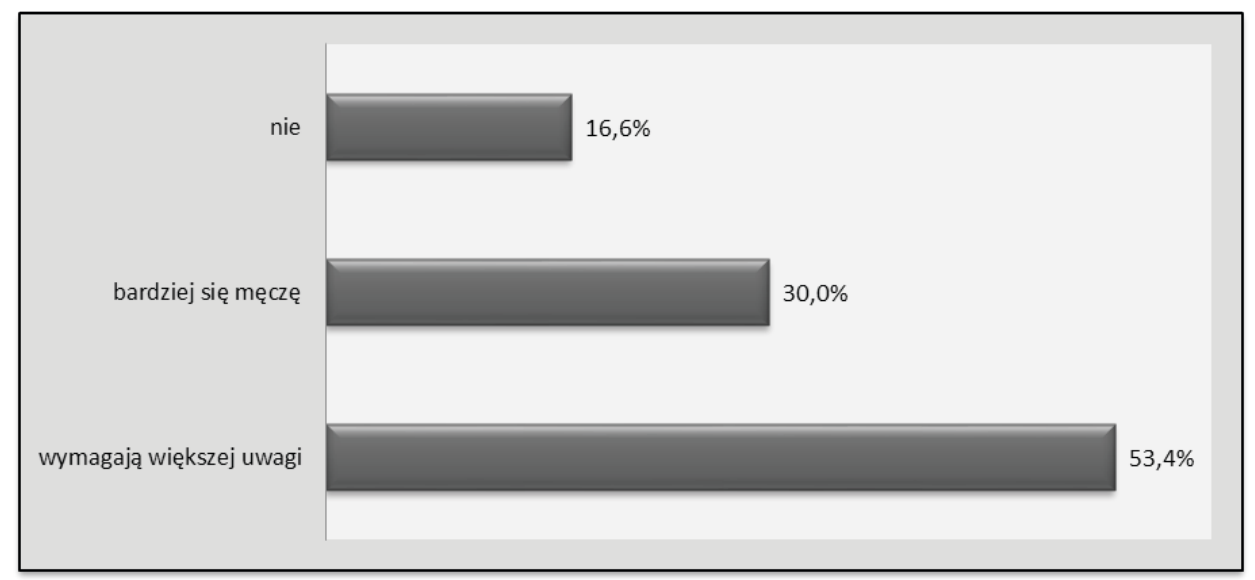

Rycina 7. Przeszkody w podejmowaniu aktywności fizycznej z przyborami

Źródło: badania własne. 
Odpowiedzi na kolejne pytanie pozwalało poznać preferencje badanych osób dotyczące znajomości i użycia poszczególnych przyborów. Okazuje się, że badani najbardziej lubią ćwiczyć z piłkami fittball, kijami do nordic walking i laskami gimnastycznymi $(58,3 \%, 53 \%, 43,3 \%)$. Rzeczywiście, przybory te są bardzo przydatne dla osób starszych, gdyż zwiększają zakres i poprawność ruchu, działają rozciągająco i odprężająco. Wydają się bezpieczne dla ćwiczących. Jako kolejne przybory badani wymieniali: przybory do aqua fitness (30,0\%), taśmy ther-band $(20 \%)$ i trener równowagi $(16,6 \%)$. Najmniej popularne okazują się piłki lekarskie $(10 \%)$ i hantle $(8,3 \%)$. Potwierdza się wiec, że badani mają problem z ćwiczeniami siłowymi, wymagają one bowiem większego zaangażowania osłabionych partii mięśniowych.

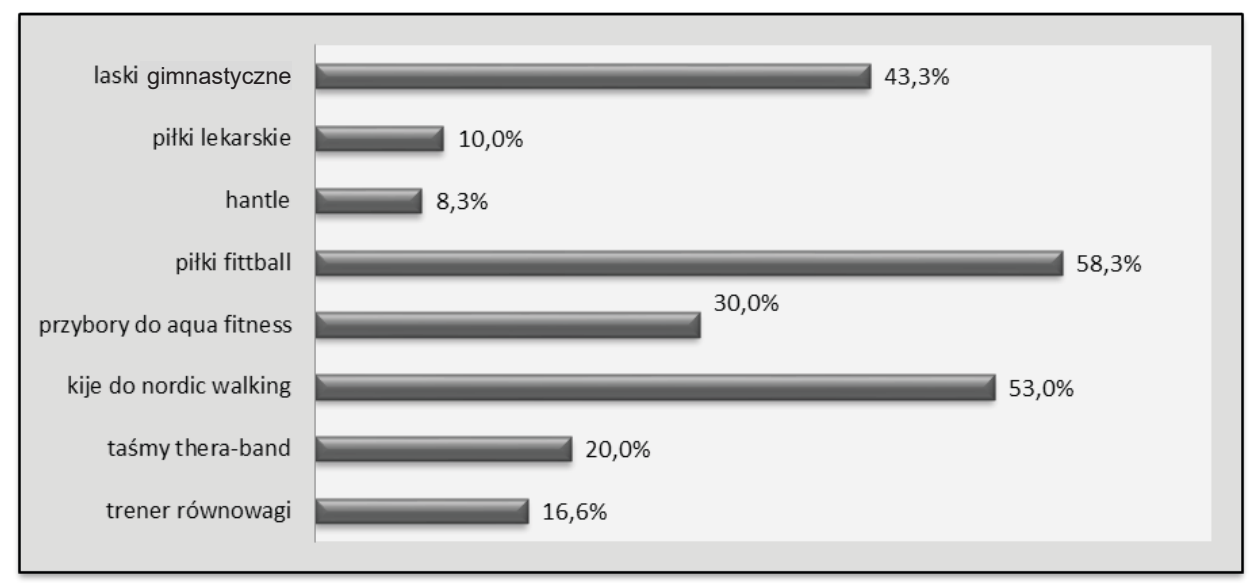

Procenty nie sumują się do 100, gdyż była możliwość wyboru więcej niż jednej odpowiedzi.

Rycina 8. Preferencje stosowania wybranych przyborów podczas aktywności fizycznej

Źródło: badania własne.

Kolejne pytanie dotyczyło wskazania powodu, dla którego osoby starsze lubią zajęcia ruchowe z przyborami. Większość ankietowanych, bo $56,7 \%$, uważa, że ćwiczenia z przyborami są ciekawe. Oznacza to, że lubią różnorodność i nowość na zajęciach ruchowych. 21,6\% wskazało, że dzięki przyborom ćwiczą poprawniej, a 16,7\% jest zdania, że przybór daje im poczucie bezpieczeństwa. Zaledwie trzy osoby uznały, że lubią gdy przybór podnosi intensywność ćwiczeń. Wynik ten po raz kolejny potwierdza, że ćwiczenia siłowe sprawiają osobom starszym trudność, co ma związek z regresem tej cechy w wieku starszym. 


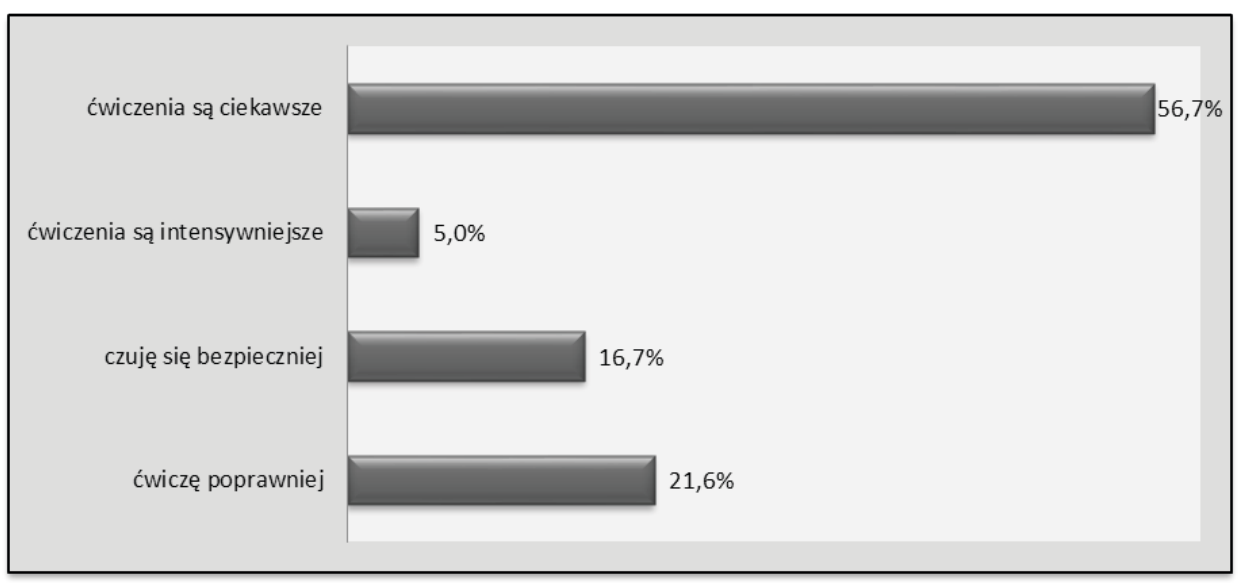

Rycina 9. Zalety w podejmowaniu aktywności fizycznej z przyborami

Źródło: badania własne.

\section{Dyskusja}

Starzenie jest naturalnym procesem fizjologicznym, jest zjawiskiem nieuchronnym związanym ze zmianami inwolucyjnymi, które powodują zmniejszenie sprawności i wydolności organizmu. Regularna aktywność fizyczna może spełniać rolę antyinwolucyjną, opóźniać procesy starzenia i pozwalać na utrzymanie zadowalającej sprawności fizycznej do końca życia. Możemy mówić wtedy o tzw. „pomyślnym starzeniu się” (Rowiński, Dąbrowski, 2011).

Liczne obserwacje dowodzą, że systematyczna aktywność ruchowa osób starszych pomaga zachować niezależny tryb życia, poprawiając zdrowie fizyczne i psychiczne (Kozdroń, 2006, Drygas, Bielecki, 2005, Osiński, 2013). Przyjmuje się, że efekty płynące $z$ regularnie podejmowanej aktywności ruchowej są korzystniejsze, gdy nawyki aktywnego spędzania czasu wolnego kształtowały się od wczesnych etapów życia i kontynuowane były w każdym okresie życia, niż te zapoczątkowane w wieku podeszłym (Bicka, Kozdroń, 2003). Trzeba jednak zawsze podkreślać, że każdy okres w życiu człowieka jest odpowiedni na podjęcie aktywności ruchowej. Obserwacje wynikające z badań własnych ukazują, że wysoka aktywność badanych seniorów jest powiązana z aktywnością w przeszłości. Jedynie $20 \%$ badanej grupy nie było w przeszłości osobami aktywnymi. Tą wysoką aktywność badanej grupy potwierdza również udział seniorów w dodatkowych zajęciach ruchowych, poza deklarowanymi w badaniach. Najwięcej z nich uprawia nordic walking, pływanie, jazdę na rowerze, narciarstwo, jedna osoba deklaruje bieganie i jedna osoba chodzenie po górach w kategorii „inne”. Wynik ten wydaje się bardzo zadowalający, pomimo że 43,3\% ogranicza się do zajęć objętych badaniami. 
W badaniach analizowano sytuację materialną osób starszych, która w dużej mierze decyduje o dostępności do zorganizowanych zajęć ruchowych. Badana grupa ocenia sytuację materialną jako wyższą od przeciętnej, co umożliwiło im zrealizowanie swoich potrzeb w tym zakresie. Jak wskazują badania (Czapiński, Panek, 2009), sytuacja materialna polskich seniorów jest jedną z najgorszych w Europie, doprowadzająca wręcz do wykluczenia społecznego. Tym bardziej wyniki niniejszych badań mogą napawać optymizmem co do zmiany obrazu złej sytuacji materialnej polskich seniorów.

Wzrost świadomości dotyczącej zachowania zdrowia i kondycji fizycznej jest istotnym czynnikiem motywacyjnym do podjęcia aktywności ruchowej. $75,3 \%$ badanych uważa, że największym plusem z bycia aktywnym jest poprawa samopoczucia, zdrowia - 50,2\%; potrzeba kontaktu z ludźmi - 58,2\%. Chęć uczestniczenia w zorganizowanych zajęciach dowodzi, że osoby starsze z chwilą przejścia na emeryturę chcą być nadal osobami aktywnymi i przebywać w grupie rówieśniczej. Dużą rolę odgrywają w tej kwestii kluby i stowarzyszenia, ukierunkowane na podnoszenie świadomości zdrowotnej i aktywizację starszych osób (np. uniwersytety III wieku).

W badaniach poruszono również kwestię przeszkód w podejmowaniu aktywności ruchowej. Zaobserwowano, że niska mobilizacja i nieśmiałość stanowią barierę w realizowaniu potrzeb związanych z aktywnością fizyczną. Ta niedostateczna mobilizacja może mieć swoje źródło w okresowym gorszym samopoczuciu psychicznymi i fizycznym, które jest charakterystyczne dla wieku starszego, a nieśmiałość wynika z niskiej samooceny, niewiary we własne możliwości.

Poza ogólnymi informacjami dotyczącymi aktywności ruchowej osób starszych, zainteresowano się również preferencjami badanych co do formy prowadzenia zajęć. Chodziło tu przede wszystkim o wykorzystanie różnych przyborów w zajęciach ruchowych. Zauważono, że seniorzy zdecydowanie wolą zajęcia ruchowe z przyborami - tak wypowiedziało się $85 \%$ badanych. $53,4 \%$ badanych uznało, że ćwiczenia z przyborem wymagają większej uwagi. Skupienie podczas ćwiczeń wpływa na zwiększenie koncentracji, co opóźnia procesy związane ze spadkiem reakcji na bodźce zewnętrzne, tak charakterystyczne dla wieku starszego. Badani seniorzy najbardziej lubią ćwiczyć z piłkami fit ball i z kijami do nordic walking. Piłka jest popularnym i bezpiecznym przyborem nastawionym na ćwiczenia oddechowe, rozciągające, odprężające. Ćwiczenia z piłką uaktywniają wszystkie partie mięśni, działają na zmysł równowagi i błędnik, poprawiają koordynację ruchową, co jest znaczące w przypadku osób w starszym wieku. Natomiast kije do nordic walking są powszechnie znane przez osoby starsze, ze względu na popularność tej formy rekreacji. Kije mogą i powinny służyć do wykonywania ćwiczeń wzmacniających i rozciągających ramiona, nogi, tułów, a poprzez podparcie dają poczucie bezpieczeństwa i pewności. Aerobowy charakter tej formy ruchu poprawia funkcjonowanie układu oddechowego i krążeniowego, koordynację ruchową i równowagę. Najmniej lubianymi przyborami są piłki lekarskie i hantle, które wymagają większej siły mięśniowej, a ta, zwłaszcza w odniesieniu do kobiet, drastycznie spada wraz z wiekiem. Przybory te wydają się więc zbyt trudne dla osób starszych. 
Badania wskazują na potrzebę włączenia przyborów do zajęć z aktywności ruchowej, gdyż podnoszą ich atrakcyjność, usprawniają psychomotorykę seniorów, dając jednocześnie poczucie przyjemności, rozrywki i odprężenia.

Jak donoszą statystyki, większość ludzi dorosłych i starszych nie podejmuje wystarczająco aktywnego stylu życia, pomimo udokumentowanych licznych korzyści z oddziaływania aktywności ruchowej na zdrowie człowieka. Zdecydowaną większość społeczeństwa cechuje bierny model spędzania czasu wolnego i sporadyczna aktywność ruchowa. Niniejsze badania wskazują na wzrost zainteresowania osób w starszym wieku aktywnością ruchową i uczestnictwem w zorganizowanych jej formach. Uznanie ważnej roli zachowań zdrowotnych w utrzymaniu i umacnianiu zdrowia, wzrost świadomości i wiedzy na temat korzyści z bycia aktywnym prowadzą do zmiany sceptycznych poglądów na temat aktywności ruchowej, co jest dobrą prognozą na przyszłość.

\section{Wnioski}

1. Aktywność badanych seniorów jest powiązana z ich aktywnością w przeszłości. Badana grupa potwierdza udział w dodatkowych zajęciach ruchowych. Najwięcej osób deklaruje chodzenie z kijami nordic walking, pływanie i jazdę na rowerze.

2. Przeszło połowa ankietowanych ocenia swoją sytuację materialną jako wyższą od przeciętnej, co pozwala na zróżnicowane zaspakajanie potrzeb w zakresie aktywności fizycznej.

3. Ankietowani ocenili, iż zaletą z bycia aktywnym jest poprawa samopoczucia, możliwość kontaktu z innymi ludźmi i poprawa zdrowia.

4. Wśród najczęściej wskazywanych przez badanych przeszkód do podejmowania aktywności fizycznej jest nieśmiałość i brak bodźca, pobudzenia do działania.

5. Przeważająca większość badanych chętnie korzysta z przyborów w trakcie ćwiczeń i wysoko ocenia zajęcia z ich udziałem. Zdaniem ankietowanych przybory uatrakcyjniają ćwiczenia oraz skłaniają do większego zaangażowania i koncentracji.

\section{Literatura}

Bicka A., Kozdroń E., 2003, Aktywność ruchowa ludzi starszych czynnikiem adaptacyjnym do określonego wysiłku fizycznego. „Kultura Fizyczna”, nr 5/6.

Czapiński J., Panek T. (red.), 2009, Diagnoza społeczna. Warunki i jakość życia Polaków, Rada Monitoringu Społecznego, Warszawa.

Drygas W., Bielecki W., 2005, Stan zdrowia, postawy i zachowania zdrowotne mieszkańców Torunia. Raport z badań wykonywanych w ramach programu CINDI WHO, Łódź.

Gębska-Kuczerowska A., 2002, Ocena zależności między aktywnością a stanem zdrowia ludzi w podeszłym wieku, „Przegląd Epidemiologiczny”, nr 56 (3). 
Kozdroń E., 2004, Program rekreacji ruchowej osób starszych, Wydawnictwo AWF w Warszawie, Warszawa, s. 32.

Kozdroń E., 2006, Rekreacja ruchowa osób „III wieku”. Zarys teorii rekreacji ruchowej, Warszawa.

Osiński W., 2013, Gerokinezjologia. Nauka i praktyka aktywności fizycznej w wieku starszym, Wydawnictwo Lekarskie PZWL, Warszawa.

Rowiński R., Dąbrowski A., 2011, Wpływ regularnej aktywności ruchowej na sprawność fizyczną i jakość życia seniorów, „Turystyka i Rekreacja”, t. 7.

Wieczorowska-Tobis K., Kostka T., Borowicz A., 2011, Fizjoterapia w geriatrii, Wydawnictwo Lekarskie PZWL, Warszawa, s. 3.

Wizner B. 2006, Prewencja gerontologiczna, (w:) T. Grodzicki, J. Kocenba, A. Skalska, Geriatria z elementami gerontologii ogólnej, Via Medica, Gdańsk. 